DOI: 10.18276/sip.2017.50/3-07

\title{
Dariusz Nowak*
}

Uniwersytet Ekonomiczny w Poznaniu

\section{FORMY WSPÓŁDZIALANIA PRZEDSIĘBIORSTW W KOOPERACJI PRZEMYSŁOWEJ}

\begin{abstract}
Streszczenie
W artykule przedstawiono i scharakteryzowano typy relacji, jakie występują między współpracującymi przedsiębiorstwami. Stwierdzono, że kooperacja opiera się przede wszystkim na relacjach prostych, do których zaliczono tzw. relacje incydentalne, powtarzalne i długofalowe, określane jako antagonistyczne, sporadycznie natomiast wykorzystuje się relacje zaawansowane, do których należy partnerstwo, sojusz i tzw. kooperacja kompletna.
\end{abstract}

Słowa kluczowe: typy i rodzaje relacji, współpraca i współdziałanie, zarządzanie relacjami

\section{Wprowadzenie}

Jednym z kluczowych czynników wpływających na długofalowy sukces organizacji jest budowa właściwych i odpowiednich relacji z kontrahentami, którzy współuczestniczą w procesie tworzenia wartości. W praktyce uważa się, że osiągnięcie korzyści wymaga tworzenia efektywnych więzi pomiędzy wszystkimi uczestnikami powstałego układu z jednej strony oraz harmonizacji procesów i działań pomiędzy nimi z drugiej (Gordon, 2001, s. 319-366). Dotychczasowe, partykularne i autonomiczne podejście do realizacji własnych celów, oparte na zindywidualizowanych kompetencjach, umiejętnościach i zasobach, skazane jest na niepowodzenie

Adres e-mail: dariusz.nowak@ue.poznan.pl 
i porażkę. Postawa taka ogranicza bowiem możliwość absorpcji innowacji, dostęp do wiedzy, nowych technologii, zasobów, a także uniemożliwia opanowanie nowych instrumentów gospodarowania zasobami materialnymi i ludzkimi. Współczesny świat wymaga zatem podejścia kooperatywnego, które należy definiować jako zgodne, zespołowe i efektywne działanie, w którym partnerzy dbają o wzajemne interesy.

Należy jednak podkreślić, że mimo dużego znaczenia formy współpracy w procesie tworzenia wartości oraz istniejącej wśród przedsiębiorców znacznej świadomości wagi wspólnej realizacji celów, relacje kooperacyjne w Polsce charakteryzują się stosunkowo niskimi poziomem i jakością. Brak zaufania, niewielkie zaangażowanie, a przede wszystkim próba realizacji własnych celów kosztem partnera, nie przyczyniają się do osiągnięcia konsensusu i kompromisu, które pozwoliłyby w pełni wykorzystać atuty i zalety kooperacji.

Wychodząc z powyższych supozycji przyjęto, że celem opracowania będzie identyfikacja i ocena typów relacji, jakie zachodzą między przedsiębiorstwami w procesie współpracy. Jako narzędzie badawcze przyjęto zmodyfikowaną typologię Webstera (1992, s. 5), który relacje kooperacyjne bada przez pryzmat rodzajów transakcji zachodzących między przedsiębiorstwami.

\section{Typy i rodzaje relacji między przedsiębiorstwami}

Współcześnie kooperacja postrzegana jest jako typowe zjawisko umożliwiające realizację określonych procesów zachodzących w przedsiębiorstwach. Podkreśla się, że konieczność wykonania zadań produkcyjnych zmusza producentów do nawiązywania różnego rodzaju relacji o zmiennym charakterze i zakresie, niejednolitej sile oddziaływania, a także różnym okresie trwania. W praktyce nie istnieje bowiem jeden, ściśle zdefiniowany typ współpracy czy współdziałania. Przedsiębiorstwa, kształtując swoje stosunki z otoczeniem, mogą wybierać określony rodzaj relacji spośród szerokiego wachlarza dostępnych alternatyw.

Przykładowo, najprostszy podział oparty jest na związkach kooperacyjnych i koncentracyjnych (Górzyński, Pander, Koć, 2006, s. 9-11). Zdaniem autorów, związki kooperacyjne dotyczą obszarów współpracy w celu zwiększenia konkurencyjności, przy jednoczesnym zachowaniu suwerenności i samodzielności działania. Związki koncentracyjne są natomiast związane z zacieśnieniem współpracy i tworzeniem powiązań kapitałowych, z jednoczesnym - częściowym lub całkowitym ograniczeniem samodzielności działania. Zdaniem Lichtarskiego (2003, s. 389-395) 
współdziałanie kooperacyjne może przyjmować formę bezumowną, umowną i koordynacyjną, a współdziałanie koncentracyjne luźną i zwartą.

Czakon (2007, s. 35-40) wskazuje, że typologia form współpracy może przybierać formy:

- powstające na poziomie zbiorowości przedsiębiorstw,

- wynikające z systemu więzi międzyorganizacyjnych,

- wynikające z pojedynczych więzi międzyorganizacyjnych.

Szerszy podział prezentuje Kaczmarek (2000, s. 36), który formy współdziałania dzieli na proste i złożone. Do form prostych zalicza: obrót towarowy między przedsiębiorstwami, kooperację produkcyjną, pożyczki, najem, dzierżawę, franchising, wspólne przedsięwzięcia oraz leasing, do złożonych natomiast: akwizycje, fuzje i alianse strategiczne.

Stosunkowo szeroka klasyfikacja form powiązań między przedsiębiorstwami została również opracowana przez Janasza i Białosiewicz (2000, s. 167-169), definiujących sześć kryteriów podziału, do których zaliczyli: formy specjalizacji, uczestnictwo w procesie współpracy, lokalizację, podporządkowanie organizacyjne, zaangażowanie podmiotów oraz okres trwania.

Podobny podział zaprezentowały Jaźwińska i Kiernożycka-Sobejko (2006, s. 610), które skomplikowane formy kooperacji charakteryzują za pomocą następujących kryteriów: obszaru, zasięgu, liczby podmiotów, efektywności, udziału partnerów w efektach, układu relacji między podmiotami, sposobu regulacji, charakteru współdziałania oraz zgodności z przepisami prawa.

Kolejna klasyfikacja, autorstwa Kale i Singh (2009, s. 46-47), wyróżnia partnerstwo kontraktowe oraz kapitałowe. W ramach pierwszego z nich identyfikuje się umowy tradycyjne oraz umowy nietradycyjne. W zakresie partnerstwa kapitałowego wskazane zostają formy takie, jak: tworzenie odrębnych podmiotów, brak tworzenia odrębnych podmiotów oraz rozwiązywanie nowych podmiotów.

Specyficzne ujęcie form współpracy prezentują również Provan i Kennis (2008, s. 229-236), którzy zidentyfikowali trzy odmienne rodzaje sieci przedsiębiorstw: zarządzane przez ich uczestników, kierowane przez organizację macierzystą oraz zarządzane przez organizację administracyjną.

Stosunkowo ciekawy podział zaprezentowali Rangan i Yoshino (1996, s. 7-9), którzy, wykorzystując kryterium ryzyka wystąpienia konfliktu oraz zakres interakcji organizacyjnej, stworzyli macierz relacji, w której zidentyfikowali cztery typy sojuszy: prekonkurencyjny, konkurencyjny, prokonkurencyjny oraz niekonkurencyjny. 
Hierarchiczny model powiązań między przedsiębiorstwami zaprezentował Webster (1992, s. 5), który uważa, że relacje w układzie dostawca-nabywca mogą stanowić stadia ewolucyjnego rozwoju współpracy pomiędzy uczestnikami transakcji. Początek układu stanowią tzw. czyste bezumowne kontrakty, przechodzące w transakcje powtarzalne, następnie powiązania długofalowe i partnerstwo. $\mathrm{Na}$ końcu układu jest przejrzysty stosunek współpracy, pomiędzy całkowicie hierarchicznie zintegrowanymi firmami.

Natura relacji między przedsiębiorstwami może też, zdaniem Bengtsson’a i Kock’a (1999, s. 181-182), przyjmować jeden z pięciu typów powiązań: kooperacji, konkurencji, kooperencji, zmowy i koegzystencji. Natomiast zdaniem Buxmanna i innych (2008, s. 248), analizując relacje zachodzące między przedsiębiorstwami, można zidentyfikować trzy scenariusze kooperacyjne: brak współpracy, kooperację zdecentralizowaną oraz kooperację scentralizowaną.

Sumując teoretyczne rozważania dotyczące rodzajów i typów relacji zachodzących między współpracującymi przedsiębiorstwami, należy zaznaczyć, że dążenie do zwiększania konkurencyjności i podnoszenia efektywności funkcjonowania przedsiębiorstw wymusza konieczność poszukiwania najbardziej optymalnego układu relacji z dostawcami. Ze względu na ograniczony przepływ informacji, dany układ może być optymalny tylko w określonych warunkach, co oznacza, że przy innym zestawie informacji, w innym czasie, i w innej przestrzeni można dokonać znaczącej rekonstrukcji powiązań w kierunku tych, które charakteryzują się wyższym standardem, innym zakresem zaangażowania, przy innych czynnikach ograniczających.

\section{Charakterystyka badanych przedsiębiorstw}

Badania empiryczne, dotyczące relacji zachodzących między współpracującymi przedsiębiorstwami, prowadzono w 2015 roku w ramach tematu dotyczącego strategii współpracy. W ich trakcie sformułowano wiele problemów szczegółowych, w tym dotyczący charakteru i natury związków, które zachodzą między podmiotami gospodarczymi. Podstawą analiz i ocen procesów zachodzących pomiędzy kooperującymi przedsiębiorstwami były wyniki pogłębionych badań ankietowych na próbie 226 podmiotów. Dobór próby miał charakter nielosowy, celowy, jednostek typowych, charakteryzujących się ugruntowaną i trwałą strukturą. 
Tabela 1. Charakterystyka badanej próby

\begin{tabular}{|c|c|c|c|}
\hline Lp. & Charakterystyka & Liczba wskazań $\mathrm{N}=175$ & Udział (w \%) \\
\hline \multicolumn{4}{|c|}{ Wielkość przedsiębiorstwa } \\
\hline 1. & średnie & 51 & 29,15 \\
\hline 2. & małe & 124 & 70,85 \\
\hline \multicolumn{4}{|c|}{ Rok założenia } \\
\hline 1. & do 1990 & 24 & 13,71 \\
\hline 2. & 1991-2000 & 61 & 34,86 \\
\hline 3. & 2001-2010 & 69 & 39,43 \\
\hline 4. & po 2010 & 21 & 12,00 \\
\hline \multicolumn{4}{|c|}{ Domena działalności* } \\
\hline 1. & produkcja & 86 & 49,14 \\
\hline 2. & usługi produkcyjne & 51 & 29,14 \\
\hline 3. & usługi okołoprodukcyjne & 129 & 73,71 \\
\hline \multicolumn{4}{|c|}{ Rodzaj obsługiwanego rynku } \\
\hline 1. & rynek lokalny & 64 & 36,57 \\
\hline 2. & rynek regionalny & 36 & 20,57 \\
\hline 3. & rynek krajowy & 63 & 36,00 \\
\hline 4. & rynek międzynarodowy & 12 & 6,85 \\
\hline 5. & rynek globalny & 0 & \\
\hline \multicolumn{4}{|c|}{ Rodzaj stosowanej strategii bazowej* } \\
\hline 1. & strategia jakościowa & 96 & 54,86 \\
\hline 2. & strategia cenowa & 77 & 44,00 \\
\hline 3. & $\begin{array}{l}\text { strategia zróżnicowana - w zależności od } \\
\text { obsługiwanych regionów, przedsiębiorstw }\end{array}$ & 54 & 30,86 \\
\hline 4. & strategia niszy & 29 & 16,57 \\
\hline 5. & strategia mieszana & 24 & 13,71 \\
\hline 6. & brak wyraźnej strategii & 12 & 6,85 \\
\hline 7. & strategia naśladowcy & 9 & 5,14 \\
\hline
\end{tabular}

* przedsiębiorstwo mogło wskazać więcej niż jedną opcję.

Źródło: opracowanie własne.

W niniejszym opracowaniu przedstawione są wyniki dotyczące rodzaju relacji zachodzących między kooperującymi przedsiębiorstwami z perspektywy małych i średnich podmiotów, których w badanej próbie było 175 (77,4\% próby).

Próba badania charakteryzowana była za pomocą wielu parametrów, takich jak: domena i profil działalności, wielkość zatrudnienia, okres działania, obsługiwane rynki oraz rodzaj wykorzystywanej strategii bazowej. Szczegółowa charakterystyka próby została przedstawiona w tabeli 1. 


\section{Rodzaje relacji kooperacyjnych z perspektywy MSP - wyniki badań}

W ramach kompleksowych badań nad kierunkami i perspektywami rozwoju kooperacji, obserwacji i analizie zostały poddane zagadnienia dotyczące rodzaju i charakteru relacji, które zachodzą między współpracującymi przedsiębiorstwami. Podstawą badania byłą zmodyfikowana typologia Webstera (1992), według której współzależność może być zidentyfikowana na kanwie sześciostopniowej skali obejmującej: brak kooperacji, proste powiązania kooperacyjne, kooperację na zasadzie konfrontacji i dysonansie, partnerstwo, sojusz, integrację.

Wykres 1. Relacje kooperacyjne MSP z odbiorcami - wyniki badań

\section{Liczba wskazań - N=175}

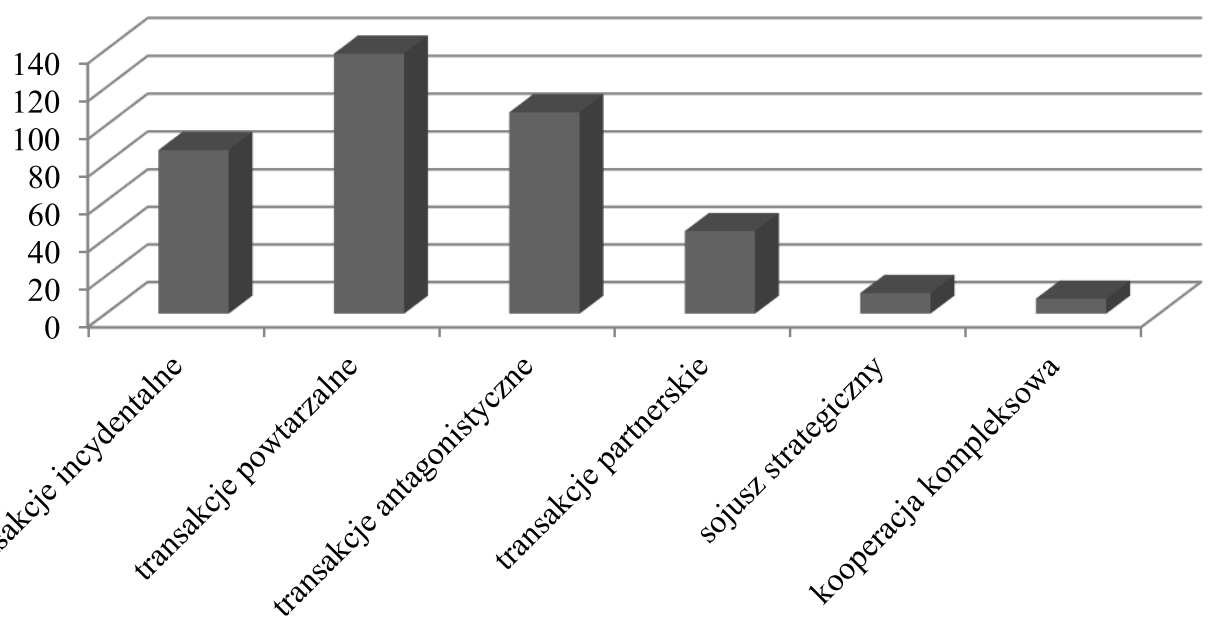

Źródło: opracowanie własne.

Przedsiębiorcy zostali poproszeni o nadanie rang wyodrębnionym typom relacji, wskazanie udziału procentowego w ogólnej wartości pochodzącej z kooperacji (problematyka ta została zobrazowana na wykresie 1) oraz określenie przedmiotu poszczególnych form.

Przechodząc do analizy uzyskanych wyników, stwierdzono, że dominujący charakter w układach nabywca-dostawca mają relacje oparte na prostych, nieskomplikowanych transakcjach, polegających na przejrzystej wymianie wartości między stronami. Forma ta została wskazana przez prawie $80 \%$ badanych (138 przedsię- 
biorstw), którzy przy jej wykorzystaniu realizują od 12 do $24 \%$ wartości dostaw pochodzących z kooperacji. W ramach wskazanej formy realizuje się dostawy materiałów eksploatacyjnych, prostych części do maszyn i urządzeń, niektórych normaliów oraz nieskomplikowanych rodzajów usług. Nawiązanie takich relacji zachodzi w wypadku, gdy strony przestają być dla siebie anonimowe, a transakcje zaczynają mieć charakter systematyczny i regularny. Dostawca podejmuje próby dostosowania swojej oferty do wymagań odbiorcy pod względem jakościowym, technologicznym, terminów dostaw, formy płatności, użyteczności itp. (Safin, 2003, s. 105). Podjęty zakres działań ma na celu tworzenia preferencji i lojalności nabywcy, dzięki czemu dostawca ma możliwość osiągnięcia wysokiej ceny i innych korzyści, które zazwyczaj wiążą się regularnością zakupów. Relacje proste nie mają sformalizowanego charakteru, opierają się na pewnym zaufaniu, przyzwyczajeniu i nawyku, które są pochodną wcześniejszych doświadczeń i kontaktów. W praktyce regulowane są przepisami prawa, dobrymi praktykami i zasadami obowiązującymi w danym sektorze.

Z punktu widzenia badanych podmiotów, istotnym rodzajem relacji jest również współpraca oparta na konfrontacji i dysonansie. Została wskazana przez 107 podmiotów, stanowiących ponad $61 \%$ próby. Przy wykorzystaniu tej formy współpracy realizuje się od 30 do $55 \%$ dostaw związanych z zaopatrzeniem surowcowym i materiałowym. Cechą wyróżniającą ten rodzaj relacji jest asymetryczne rozłożenie sił między kontrahentami, co powoduje rozwój stosunków antagonistycznych i konfrontacyjnych, skupionych głównie na walce o niską cenę.

Kolejnym typem relacji wykorzystywanym w układach nabywca - dostawca są tak zwane transakcje incydentalne, określane również jako sporadyczne, jednorazowe czy dyskretne. Charakteryzuje się je przez wąski zakres informacji, ograniczony system komunikacji oraz niewielką skalę wymiany. Zostały wskazane przez 87 respondentów stanowiących prawie 50\% próby. Dotyczą jednak niewielkiego zakresu zaopatrzenia, którego zakres kształtował się w przedziale od 4 do $10 \%$ i związany był z nabywaniem prostych materiałów eksploatacyjnych, standardowych części zamiennych oraz wąskiego zakresu usług, głównie okołoprodukcyjnych.

Omówione typy relacji dotyczą prostych powiązań kooperacyjnych, w których brak jest ścisłych, współzależnych i kompatybilnych związków. Każdy uczestnik rynku realizuje własne cele, często kosztem partnera, a w układach relacyjnych dominuje nieufność i brak zaangażowania w tworzenie wspólnych standardów.

Kolejnym typem relacji wskazanym przez badaną grupę było partnerstwo, które przyczynia się do rozwoju dużej współzależności między współpracującymi partnerami. Ten typ transakcji został wskazany przez 44 badanych, którzy stano- 
wili $25 \%$ próby. Wartość realizowanych kontraktów stanowiła stosunkowo szeroki wachlarz o rozpiętości od 15 do 55\% zakupów. Wskazano, że w ramach partnerstwa nabywa się strategiczne surowce, części, detale i fabrykaty oraz profesjonalne usługi produkcyjne. U podstaw tworzenia tego typu powiązań leży przekonanie, że jakość i niski koszt działalności zależą w dużym stopniu od współpracy z małą liczbą dostawców, którzy są zaangażowani we wczesnych fazach rozwoju produktu, tworząc układ kooperacyjny nieznany w antagonistycznych formach pozyskiwania zasobów. W tej formie współpracy często występuje asymetryczne rozłożenie sił, przy czym dominujący partner nie wykorzystuje swojej pozycji, a działania przez niego podejmowane uwzględniają interesy kontrahenta.

Pozostałe dwa typy współpracy wskazywane były sporadycznie. Sojusz strategiczny w budowie międzyorganizacyjnych więzi wykorzystywany jest przez 11 firm, stanowiących $6 \%$ próby, a kooperacja związana z synchronizacją i kompatybilnością procesów przez 8 przedsiębiorstw (4,5\% badanych). Sojusz polega na intensyfikacji współpracy w celu osiągnięcia długofalowej przewagi konkurencyjnej. Kooperacja kompleksowa natomiast dotyczy tych firm, które łączą swoje kluczowe zasoby w celu wykorzystania efektu synergii. U podstaw rozwoju tych relacji leży dążenie firm do poprawy lub radykalnych zmian pozycji konkurencyjnej. Zasadniczą zaletą tego rodzaju powiązań jest wysoka elastyczność, podmioty mogą bowiem dowolnie kształtować zakres i zasięg współpracy, mogą go modyfikować oraz w przypadku braku zgodności, rozwiązać.

\section{Podsumowanie}

Wyniki badań wskazują, że przedsiębiorstwa w procesie kooperacji nie ograniczają się do jednego typu relacji. W zależności od pozycji, posiadanych atutów, aktualnych potrzeb i realizowanej strategii budują różne układy, w których wykorzystują rozmaite instrumenty i narzędzia zarządzania.

Dominujący charakter mają tzw. układy proste, do których zalicza się współpracę jednorazową, powtarzalną i długofalową. W relacjach tych wykorzystuje się twarde mechanizmy oddziaływania na partnera, takie jak: nacisk, presja, a nawet szantaż. Podstawą tworzenia takich układów jest konformizm i wygodnictwo, bowiem konieczność zaangażowania się w relacje ograniczające własne możliwości rozpatrywana jest przez pryzmat próby zdominowania przez partnera, a nie przez pryzmat możliwości zwiększenia efektywności. Ponadto rozwój relacji kooperacyjnych jest 
kosztowny i mało efektywny w pierwszych okresach współpracy i nie gwarantuje osiągnięcia zamierzonych celów. Doświadczenia przedsiębiorców wskazują bowiem, że w praktyce często nie przestrzega się podstawowych założeń porozumienia, w tym terminów dostaw, jakości wyrobów i przede wszystkim terminów płatności.

W układach o bardziej skomplikowanej strukturze, które opierają się na wzajemnym zrozumieniu, zaangażowaniu, a także dbałości o interesy partnera, przeważa kompromisowość, elastyczność i dążenie do konsensusu. Wskazuje się tutaj na takie relacje, jak partnerstwo, sojusz strategiczny oraz kooperacja koordynacyjna. Rozwój takich relacji przyczynia się do wzrostu pozycji rynkowej, osiągania większych przychodów i zysków, a także poprawy wizerunku i opinii o podmiocie na rynku. Niestety, w realiach Polski relacje te mają drugorzędny charakter, wykorzystywane są sporadycznie i na małą skalę.

\section{Literatura}

Bengtsson, M., Kock, S. (2000). "Coopetition" in Business Networks - to Cooperate and Compete Simultaneously. Industrial Marketing Management, 14 (29).

Buxmann, P., von Arsen, A., Diaz, L.M. (2008). Economic evaluation of cooperation scenarios in supply chains. Journal of Enterprises Information Management, 21 (3).

Czakon, W. (2007). Dynamika więzi międzyorganizacyjnych przedsiębiorstwa. Katowice: Prace Naukowe Akademii Ekonomicznej.

Gordon, I.H. (2001). Relacje z klientem. Marketing partnerski. Warszawa: PWE.

Górzyński, M., Pander, W., Koć, P. (2006). Tworzenie zwiazków kooperacyjnych między MSP oraz MSP i instytucjami otoczenia biznesu. Warszawa: PARP.

Janasz, W., Białasiewicz, M. (red.) (2000). Elementy strategii rozwoju przemystu. Szczecin: Wydawnictwo Naukowe Uniwersytetu Szczecińskiego.

Jaźwiński, I., Kiernożycka-Sobejko, A. (2006). Kooperacja i konkurencja w rozwoju społeczno-ekonomicznym w aspekcie międzynarodowej współpracy regionów. Nierówności Spoleczne a Wzrost Gospodarczy, 8.

Kaczmarek, B. (2000). Wspótdziałanie przedsiębiorstw w gospodarce rynkowej. Łódź: Wydawnictwo Uniwersytetu Łódzkiego.

Kale, P., Singh, H. (2009). Managing strategic alliances: what do we know now, and where do we go from here? The Academy of Management Perspectives, 3.

Lichtarski, J. (red.) (2003). Podstawy nauki o przedsiębiorstwie. Wrocław: Wydawnictwo Akademii Ekonomicznej im. Oskara Langego we Wrocławiu.

Provan, K.G., Kenis, P. (2008). Modes of Network Governance: Structure, Management, and Effectiveness. Journal of Public Administration Research and Theory, 2. 
Rangan, U.S., Yoshino, M.Y. (1996). Forging alliances: A guide to top management. The Columbia Journal of World Business, 3.

Safin, K. (2003). Zarządzanie mała firma. Wrocław: Wydawnictwo Akademii Ekonomicznej im. Oskara Langego we Wrocławiu.

\title{
FORMS OF THE COLLABORATION OF ENTERPRISES IN INDUSTRIAL COOPERATION
}

\begin{abstract}
The article presents the theoretical and empirical deliberation concerning the behavior of enterprises in the process of cooperation. It was found, that cooperation between enterprises in Poland is based on very simple relation, such as: pure transaction, repeated transaction and long-term, define as antagonistic relations. It should be emphasized, that advanced relationships, such as buyer - seller partnership, strategic alliances and total cooperation were used very seldom.
\end{abstract}

Translated by Alicja Nowak

Keywords: types and forms of cooperation, cooperation and collaboration, management of relationships

JEL Codes: O25, O47, P13 